REVISTA DE LITERATURA E CULTURA RUSSA

\title{
Púchkin e Machado, o ser negro, formas de ouvir o outro
}

\section{Pushkin and Machado, being Black, ways of listening to the other}

Autor: Susana Fuentes

Edição: RUS Vol. 11. № 15

Data: Junho 2020

https://doi.org/10.11606/issn.2317-4765. 


\section{Púchkin e Machado, o ser negro, formas de ouvir o outro}

Susana Fuentes*

Resumo: Este estudo pretende, em leituras de Púchkin e aproximações de Machado, analisar, em perspectiva comparada, o lugar de visibilidade da herança afrodescendente em Aleksander Púchkin (1799-1837) na literatura russa e Machado de Assis (18391908) na literatura brasileira. Perceber, entre margem e centro, a voz plural e inovadora do autor russo, seus caminhos até o outro. Em Puchkin, a viagem. Fronteiras possíveis. 0 olhar para si que se deixa atravessar pela diferença. Em Machado, seu olhar para as máscaras sociais e para a escravidão. Nesses autores, marcas em sua literatura que formam a sua casa e o seu tempo, em diálogo com a modernidade. $\mathrm{Na}$ abertura para o outro, leituras onde o que estava no lugar do cânone também se modifica, escurecendo o imaginário nos novos contextos.

\begin{abstract}
Readings of Pushkin and approaches to Machado: the present study aims at analyzing within a comparative perspective the space of visibility of the Afro-descendant heritage in Alexander Pushkin (1799-1837) in Russian Literature - and Machado de Assis (1839-1908) in Brazilian Literature. As well as perceiving Pushkin's plural, ingenious voice considering the tensions between margins and centers, and the singularity of each encounter with the Other. Pushkin's voyage, possible borders. The encounter with the difference and getting impacted by otherness. Machado's critical reading of social masks and slavery. Marks within the works of these two authors that shape their home and their time in dialogue with modernity. In the opening to the Other, experiences of reading as they modify the canon, darkening the literary imagination and raising new contexts.
\end{abstract}

Palavras-chave: Aleksandr Púchkin; Machado de Assis; Afrodescendência; Estudos comparados de literatura russa e brasileira

Keywords: Alexander Pushkin; Machado de Assis; Afro-descendant; Comparative studies in Russian and Brazilian literatures 


\section{Primeiras linhas}

* Doutora em Literatura Comparada pela Universidade do Estado do Rio de Janeiro (UERJ) e Pós-Doutora pela mesma universidade (bolsa CAPES/FAPERJ), escritora.

E-mail: fuentes.susana@gmail. com https://orcid.org/0000-00015529-6900
Escurecer a folha. Uma escolha, um gesto. Penso na página feita de pedaços, vestígios. Machado em seu contexto afrodescendente. Nesse colar e recolar, no escurecimento da folha, percursos de encontro com Machado, em suas marcas de alteridade, e pensar o ser negro em Púchkin. Nesse olhar, ele e Machado se aproximam. E resolvo perguntar: de que modo estar fora do centro provoca e marca o espírito agudo de sua escrita? Esse espaçamento onde se é o mesmo e o outro. E resolvo olhá-los no papel - em vestígios - no mapa. Pela marca de uma idade antiga, um retrato com pistas das diásporas, dispersões, distâncias. Na reinvenção do cânone, no diálogo entre a literatura russa e a literatura brasileira.

Púchkin me faz procurar no mapa. O lago Chad. O local de origem de seu bisavô materno. Por causa de Púchkin nascem para mim novos pontos, fendas, relíquias. Fazer a pergunta sobre o risco, ou fenda, essa demora para que algo ali se instale. Sobre os silêncios, um olhar em direção a, um olhar em movimento que se abre como pergunta. Ser negro, dizer a negritude. Sim, ainda é preciso dizer. Ainda há surpresas. O leitor comum ainda se espanta e ouvimos a pergunta, Machado de Assis, agora eu sei, agora sabemos, mas... e Púchkin também?

\section{Ode à liberdade. 0 céu africano}

Púchkin, nascido em Moscou em 1799, é celebrado como o fundador da literatura russa moderna e as diferentes gerações de autores russos dialogam e se deixam atravessar pelo olhar

1 Este trabalho parte de minha pesquisa apresentada no $14^{\circ}$ Congresso Internacional da Associação de Estudos Brasileiros (BRASA), em julho de 2018 na PUC-Rio, com o título: "O mesmo e o outro em Púchkin e Machado, o ser negro, diálogos com o contemporâneo", integrando o Painel "Perspectivas Contemporâneas dos Estudos da Literatura Afrodescendente no Brasil". 
inovador em sua obra. Por seus escritos sobre a liberdade e seu assim considerado "espírito subversivo", foi exilado em Odessa e esteve também confinado na propriedade da família em Mikháilovskoie, até lhe ser permitido viajar novamente a Petersburgo. Lá ele conhece Natália Gontcharóva, com quem se casaria. Púchkin morre após o duelo com o barão D’Anthès, em 1837.

Amigos muito próximos de Púchkin foram revoltosos dezembristas e se inspiram em seus escritos, como no seu Ode à Liberdade, para se opor à opressão do regime tsarista e exigir reformas por parte de Alexandre I, que abandonara a implementação de uma política liberal. Com a morte do tsar, sufocados por seu sucessor, o repressivo Nicolau I, cinco amigos de Púchkin foram enforcados. Nos arquivos da época, lemos o depoimento prestado por P. Bestújev depois da revolta de 14 de dezembro de 1825: "As ideias liberais germinaram em meu cérebro depois da leitura de alguns poemas manuscritos, tais como Ode à Liberdade, O Populacho, Meu Apolo, e de certas cartas devido às quais nosso célebre poeta Púchkin fora importunado". ${ }^{2}$ Púchkin não participou do levante por estar no exílio. Mas agentes tentam implicá-lo na revolta. Será poupado por Nicolau I, mas este se autonomeará censor de suas obras.

Elena Vássina, em seu artigo "Boris Schnaiderman e Aleksandr Púchkin: dois iniciadores", ressalta a análise no prefácio para A Dama de Espadas, por Boris Schnaiderman, sobre a origem africana do bisavô de Púchkin, Abraão Anibal. Segundo as pesquisas mais recentes, era natural do antigo Sudão Central, região sul do lago Chad e ao norte de Camarões, filho de um chefe africano. No artigo, Elena Vássina aponta:

É interessante prestar atenção às páginas do Prefácio dedicadas à inacabada novela "O Negro de Pedro, o Grande" onde Boris Schnaiderman, ao abordar as interligações da obra com a biografia do próprio Púchkin, estuda a questão das raízes africanas do poeta, sempre debatida entre historiadores da literatura. "O Negro de Pedro, o Grande", narra a vida 
de Anibal, bisavô de Púchkin pela linha materna. É bastante conhecido que Púchkin se referiu diversas vezes em sua obra - e com orgulho - a suas origens africanas. Contudo, há quem tenha defendido uma outra versão da história, ou seja, a de que Púchkin não seria descendente dos negros. Neste contexto, Boris Schnaiderman cita o destacado historiador literário Dmítri Mirsky e o antropólogo Anútchin - o último, "imbuído de preconceitos racistas, não podia conceber que um negro desempenhasse papel tão importante e fosse um antecessor direto do poeta nacional russo". ${ }^{3}$ Segundo as pesquisas de Dieudonné Gnammankou, do Benin, o bisavô de Púchkin teria sido levado aos oito anos para a corte do sultão turco em Constantinopla. Um embaixador russo o teria enviado como presente a Pedro, o Grande. E o tsar, como grande modernizador, talvez para copiar as tendências da corte francesa, decidiu ficar com o menino na Rússia. Lá ele o batizou, tornando-se seu padrinho. Pedro visitou a França em 1717 e neste mesmo período enviou Abraão para estudar lá. Voltou oficial de artilharia e com outro nome: Ganibal (Anibal), e tornou-se um respeitado engenheiro militar. Viveu até o reinado de Catarina, a Grande. Morreu apenas 18 anos antes do nascimento de Púchkin. ${ }^{4}$

Fazia parte do projeto de Púchkin escrever sobre seu bisavô Abraão. E ao criar o personagem Ibraim em sua obra inacabada O Negro de Pedro, o Grande, é notável como não se esquiva de revelar espaços de desconforto, o lugar fora do centro desse protegido de Pedro. Ibraim se move por terrenos escorregadios, entre inclusão e exclusão, encantos do personagem que se revelam no mal-estar do exotismo ou sobressaltos, em observações do narrador ou no diálogo dos personagens. Como na situação em que Ibraim é imposto como noivo a Natacha, que está apaixonada por outro, e assim adoece. Quando Natacha sai do delírio, conversa com a criada: "- Sabes, Andorinha? - disse ela. - Papai vai casar-me com o negro". E a criada, uma anã, conta que ninguém irá intervir a seu favor: "Durante a sua doença, o negro teve tempo de encantar a todos. O patrão está maluco por ele, o príncipe não tem outro assunto e Tatia-

3 VÁSSINA, 2018, p.63.

4 Cf. SCHMEMANN, 2010. 
na Afanássievna sempre diz é pena que seja negro, mas seria até pecado desejar noivo melhor". ${ }^{5}$

O que conduzira a tal situação fora a "inesperada atividade casamenteira do tsar" e percebemos que Ibraim, o noivo, pelo tom irônico do narrador e protestos do personagem, estava satisfeito com a vida de solteiro: "- Meu soberano", diz Ibraim,

sou feliz com a proteção e as bondades de Vossa Majestade comigo. Que Deus dê ao meu tzar e benfeitor vida mais longa que a minha, é tudo quanto desejo. No entanto, mesmo que eu pretendesse casar-me, a moça e a família concordariam? O meu físico... ${ }^{6}$

Anteriormente, em Paris, antes da volta a Petersburgo, Ibraim já tivera contato com certa condessa e percebe como na sociedade o olhavam como raridade. Talvez por isso atuasse sem expectativas e "demoras francesas" e é aí que desperta o interesse da condessa de D.

A noção de que a natureza não o criara para ser correspondido nas suas paixões fizera com que se libertasse da presunção e de quaisquer pretensões de amor-próprio, o que acrescia de raro encanto as suas relações com as mulheres. A sua prosa era simples e solene; ele agradou à condessa de D., que estava cansada das eternas pilhérias e das alusões sutis do humor francês. Ibraim frequentava muito a sua casa. Aos poucos, ela se habituou à aparência do jovem negro e até começou a ver algo agradável naquele cabeça crespa que negrejava entre as perucas empoadas do seu salão de recepções (Ibraim fora ferido na cabeça e usava uma atadura em lugar de uma peruca). Tinha ele então 27 anos, e era alto e esbelto; mais de uma beldade o encarava com um sentimento mais lisonjeiro que a simples curiosidade, mas o desconfiado Ibraim ora não notava nada, ora via apenas faceirice. $^{7}$

Segundo Mike Phillips, curador convidado da British Library, agora Púchkin aparece como uma figura capaz de usar diferentes camadas de sua identidade para criar e inspirar novos modos de ver e novas abordagens culturais. Ele conta que

5 PÚCHKIN, 1981, p. 30.

6 Ibidem, p25.

7 Ibidem, p.5. 
Púchkin, quando deixou a escola em 1814, havia estado com o último filho ainda vivo de Abraão, o irmão de seu avô Pedro. Em 1825, expressou em seus diários o desejo de ouvir dele algumas memórias de seu bisavô. E depois de uma semana voltava com uma biografia inédita de Abraão e um caderno de memórias sobre a família escritas por Pedro. E Mike Phillips contempla a seguinte possibilidade: "No entanto, mesmo com os fatos em mãos, não há evidência de que seu protagonista, Ibraim, compartilhasse as experiências do Abrão Anibal real. Talvez o racismo que envolve a personagem no romance venha da própria experiência de Púchkin".8

Percebemos em Púchkin o orgulho de seu bisavô - como no romance em versos Eugênio Onêguin, obra que começou a escrever no exílio - na distância, o voo poético até o céu de sua África: "Chorar sob o meu céu Africano", diz o verso na tradução por Alípio Correia de Franca Neto e Elena Vássina dos Capítulos I-IV que integram o primeiro volume do romance. ${ }^{9} \mathrm{E}$ em nota de pé de página aprendemos que na primeira edição do Capítulo I havia um longo comentário autobiográfico, que é suprimido na edição de 1833. Púchkin escrevera: "o autor, por parte de mãe, é de origem africana. Seu bisavô, Abram Petróvitch Annibal, aos oito anos de idade, foi sequestrado e levado da costa africana para Constantinopla..." ${ }^{10}$

No diálogo com essa herança o autor russo não deixa, porém, de revelar desajustes. Quando escreve sobre seu bisavô - o afilhado do tsar - na figura de Ibraim, nas feições de seu personagem revela a inadequação a um ideal europeu. Esse saber-se olhado - com afeição ou com curiosidade? Podemos de fato nos perguntar: até que ponto o autor deixa de falar memórias que possivelmente o tenham atravessado? Ibraim intuía que era para as mulheres

uma espécie de bicho raro, uma criatura diferente, estranha ao mundo, para o qual fora transportada casualmente e com o qual nada tinha em comum. Chegava até a invejar

8 PHILLIPS, s.d., tradução minha.

9 PÚCHKIN, 2019, p. 67.

10 Ibidem, p. 66-67. 
pessoas que passavam despercebidas e considerava a insignificância delas uma felicidade. ${ }^{11}$

Lemos, ainda:

A condessa recebeu Ibraim de modo cortês, mas sem nenhuma atenção especial, e isto o lisonjeou. Geralmente, olhava-se para o jovem negro como para um fenômeno. Rodeavam-no, bombardeavam-no com saudações e perguntas, e embora essa curiosidade viesse coberta de condescendência, assim mesmo ofendia o seu amor-próprio. ${ }^{12}$

No romance, Ibraim está integrado aos círculos sociais e, ao mesmo tempo, pode percebê-lo de fora, nas tensões ou exotismos colocados em evidência por seu formato de rosto, cabelos ou cor da pele.

Entre as "Reminiscências e materiais biográficos sobre Púchkin" reunidos no Caderno de Literatura e Cultura Russa no dossiê dedicado ao autor (2004), há o registro de um episódio do poeta russo em seu quarto em Odessa, em "excelente disposição de espírito" junto ao amigo Mouro Ali, originário da Tunísia e ex-capitão de um navio. Púchkin estava sentado sobre os joelhos de Mouro - conta o amigo Liprandi, que viajara com Púchkin à Bessarábia por nove dias, em 1821. O Mouro Ali

gostava de Púchkin, que por sua vez o tratava de corsário... Minha aparição não fez Púchkin mudar sua atitude... Púchkin elogiou-me o Mouro e acrescentou: "Sinto-me unido a ele, quem sabe, meu avô não era parente próximo de um ancestral dele?"13

No mesmo depoimento, Liprandi alude à insatisfação de Púchkin em Odessa, "em razão da própria sociedade que ele, ao que parece, sentia-se mais ou menos na obrigação de frequentar". E acrescenta: "ele perdera o hábito e o gosto dos círculos aristocráticos e familiares regidos pela etiqueta". ${ }^{14}$

11 PÚCHKIN, 1981, p.5.

12 Idem.

13 ANDRADE, Op.cit., p.152.

14 Idem. 


\section{De espelhos, olhares fora do centro, distanciamentos}

Nesse universo das aparências, lembremos do conto "O Espelho", de Machado de Assis. A alma interior e a alma exterior parecem propor um olhar presente em romances e ao longo de uma série de contos do autor. A aparência, a posição social, títulos são vistos com um distanciamento crítico. A ironia perpassa os elementos que aparecem com naturalidade no discurso das personagens. A sociedade observada por Machado é também a complexidade do indivíduo na sua constituição íntima, na subjetividade que se forma a partir de si e no encontro com o outro. Em "O Espelho - o esboço de uma nova teoria da alma humana", uma lista do que pode ser a alma, esse outro exterior, "pode ser um fluido, um homem, muitos homens, um objeto, uma operação":

O ofício da segunda alma é transmitir a vida, como a primeira; as duas completam o homem, que é, metafisicamente falando, uma laranja. Quem perde uma das metades, perde naturalmente metade da existência; e casos há, não raros, em que a perda da alma exterior implica a da existência inteira. ${ }^{15}$

E se reconhece que "separar ambas as instâncias é sempre uma operação ingrata, mas em caso de perigo à consideração pública, a alma exterior, terá primazia".

Ora, em diferentes obras do autor russo podemos buscar esse olhar de viés, novos ângulos embaralhando o centro. Espelhamentos, formas de olhar, contradições. Quem é este outro que se revela no mesmo?

Em seu poema narrativo O Cavaleiro de Bronze (1833), Púchkin fala do sujeito esmagado pelo peso da cidade, na inundação de Petersburgo, esta cidade criada por Pedro, o Grande, o próprio Cavaleiro representado na estátua. Ali, sob o monumento de bronze, o tema do homem pequeno, о ма'ленький челове'к. О pobre sujeito sentindo-se culpado por dar um murro na estátua, que paira na cidade construída sobre o pân-

15 MACHADO, 2016, p. 346. 
tano. A cidade-símbolo de sua perda: a sua noiva que morrera na inundação cantada no poema.

É significativo que Púchkin, apesar de lhe ter sido encomendado pelo tsar Nicolau I escrever sobre Pedro, o Grande ${ }^{16}$, dê início a outra pesquisa, sobre o cossaco Pugatchióv e a rebelião contra o poder imperial, nos Arquivos do Império. $O$ autor dará vida ao rebelde, em seu lado nobre de "bandido" insurgente, no romance $A$ Filha do Capitão, que espera publicar na sua revista literária trimestral 0 Contemporâneo (Совреме'нник), fundada por Púchkin em 1836. Em sua investigação, irá visitar os lugares da revolta de Pugatchióv, o cossaco com largas calças de tártaro.

Em O chefe da estação, conto que pertence ao ciclo dos Contos de Biélkin, Púchkin cria o autor fictício Ivan Petróvitch Biélkin. Esse autor-narrador anuncia logo nas primeiras linhas que o chefe da estação não é o culpado de tudo, como costumam lhe infligir. E defendendo suas dores, embaralha as expectativas sobre sua figura. E nesse conto podemos distinguir esse distanciamento, quebra de lugares fixos sobre o que se apresenta como certo. "O que é um chefe de estação? Um verdadeiro mártir de décima-quarta classe, defendido pelo seu título unicamente contra agressões corporais, e assim mesmo, nem sempre". ${ }^{17} \mathrm{E}$ anuncia: "Não é um verdadeiro trabalho forçado?" Para completar, o viajante descarrega nele toda a irritação pelo cansaço da viagem. Com fina ironia, o narrador exorta o leitor a perceber tudo isso para que, em vez de indignado, tenha sincera compaixão. E protesta, ainda: "a classe dos chefes de estação foi apresentada à opinião pública sob o aspecto mais falso". De novo, essa troca dos lugares sociais: se os viajantes não querem dar ouvidos ao chefe de estação, "quanto a mim, confesso que prefiro a sua palestra às falas de algum funcionário de sexta classe, viajando a serviço" ${ }^{18} \mathrm{E}$ a décima quarta classe era a última na hierarquia dos funcionários públicos na Rússia tsarista. E, pronto para começar a história:

16 Cf. ANDRADE, Op.Cit., p. 132-133.

17 PÚCHKIN, 1981, p.115.

18 Ibidem, p. 116. 
"pode-se adivinhar facilmente que tenho amigos entre a digna categoria dos chefes de estação. Com efeito, a memória de um deles me é preciosa", o narrador se interrompe para refletir sobre o "servo criterioso" da casa de um governador que passava por ele sem servi-lo. E como por muito tempo não pôde habituar-se a isso:

Realmente, o que seria de nós, se em vez da regra cômoda para todos o titulo respeita o título, se introduzisse em uso uma outra, por exemplo a inteligência respeita a inteligência? Que discussões não surgiriam! E por quem começariam os criados a servir a comida? Mas eu volto à minha história. ${ }^{19}$

E na história, a parábola do filho pródigo será contada, de certo modo, às avessas. A filha do chefe da estação será quem parte, e com um estranho. No entanto, não parece infeliz. Em vez de se perder, parece ter encontrado um caminho possível, ainda que com culpa, uma escolha. Os desajustes, porém, acompanham toda a narrativa. O narrador fica entre diferentes tempos: entre a lembrança da menina que conheceu na casa do chefe da estação, o encontro com o pai que lamenta a filha perdida e a descoberta do retorno dessa filha pródiga por intermédio de um menino do povoado. A cada vez, um desencaixe. O retorno da filha se dá depois de findarem quaisquer possibilidades de encontro (o pai morreu) e apreendemos, pelos ouvidos do narrador, a visão do menino - a dama tinha procurado há pouco pelo chefe da estação. O menino conta como ela seguira até o túmulo. Desceu de uma charrete, com crianças, ama, e ainda cuidou para que não faltasse ao menino uma moeda, e ao túmulo, uma cruz. No sentido que lhe atribuía o pai, essa filha não se perdeu. A perda se faz sentir no silêncio, na impossibilidade de se comunicar, de fazer a palavra chegar ao outro. Assim Púchkin rompe com o que é conhecido pelo leitor quanto à parábola do filho pródigo e nesses desencontros entre os personagens, ou de suas expectativas, o narrador segue as pistas e conta a história a partir de uma ausência. Nesse final, em que as personagens convergem para o mesmo espaço em tempos diferentes e se perdem uma das outras. E seguem suas vidas. 
Não seria aqui novamente esse olhar de Púchkin para o avesso das coisas? Helena Nazario chama a atenção para a minúcia com que o narrador viajante descreve os quadros na parede da casa do chefe da estação - quadros com cenas da parábola do filho pródigo. Para então observar que na "narrativa engendrada por Púchkin [...] a cada passo o leitor aguarda em vão a reprodução das cenas dos quadrinhos da parábola". ${ }^{20}$ $E$ adiante, conclui: "O autor oferece em troca uma nova leitura, criativa e surpreendente, opondo à estética do clichê, da repetição, uma estética de oposição, de recusa da norma". ${ }^{21}$

\section{Paradoxos}

Em Púchkin, Boris Schnaiderman lembra que a personagem do conto Dubróvski, ao mesmo tempo em que tranca a porta para que as pessoas não saíssem do celeiro incendiado, sobe no telhado e se arrisca para salvar o gato. Desse gesto acena para um terreno do humano a que seremos apresentados em Dostoiévski. Também Ralskólnikov de Crime e Castigo guarda uma centelha do reflexo de Hermann em A Dama de Espadas, de Púchkin, ele diz.

Basta ler, por exemplo, o episódio do incêndio da casa de Dubróvski, na novela do mesmo nome, aquele episódio em que o ferreiro Arkhip, que trancou a porta da casa incendiada, a fim de não escaparem dela os funcionários ali instalados, e que, no entanto, arrisca a vida, ao salvar um gato sobre o telhado em chamas, para constatar que há em Púchkin uma compreensão da complexidade dos caracteres humanos que já prenuncia Dostoiévski. ${ }^{22}$

Curiosamente, podemos buscar essas contradições em diferentes obras do poeta russo, como em seu narrador Biélkin no inacabado "A história do povoado de Goriúkhino", cujos fragmentos reunidos foram publicados após a sua morte. Atentemos para este trecho da viagem de retorno de Biélkin ao seu pequeno povoado:

20 NAZARI0, 2004, p.83.

21 Ibidem, p. 84.

22 SCHNAIDERMAN, 1981, p.1. 
Apesar da natureza tranquila do meu caráter, a impaciência para ver o local onde passara os meus melhores anos apoderou-se de mim de tal modo que a todo instante apressava o meu cocheiro, ora prometendo-lhe dinheiro para vodca, ora ameaçando-lhe com uma surra; e como era mais cômodo empurrar-lhe as costas do que tirar e desamarrar o saquinho de dinheiro, confesso que bati nele umas três vezes, coisa que nunca havia me acontecido, pois a classe dos cocheiros, nem eu mesmo sei por que, é por mim particularmente querida. ${ }^{23}$

Assim, Púchkin instaura quebras, ironias, disparates de ações. Há um episódio no drama histórico Boris Godunov, cena do personagem Nikolka, chamado Idiota, a quem as crianças roubam um copeque, que o pobre acabara de ganhar - "Levaram o meu copeque; ofenderam o Nikolka!" clama ao tsar Boris que deixava a Catedral: "Boris, Boris! As crianças ofenderam Nikolka" e pede que mande degolar as criancinhas como fez com o pequeno tsarévitche. Diante da acusação contida na súplica, o boiardo que acompanha o tsar quer enxotá-lo dali, no que Boris intervém: "Deixem-no. Reza por mim, pobre Nikolka". E após a saída do tsar, o Idiota contradiz a própria súplica: "Não, não! É proibido rezar pelo tsar Herodes. A Mãe de Deus não permite". ${ }^{24}$

Púchkin no caminho fundador, em diálogo com o seu tempo, e provocando seu tempo, vai às feiras colher a fala popular, pregões de vendedores, "ladainhas de mendigos, profecias de loucos mansos, imprecações e pragas de bêbados e prostitutas, maldições e esconjuros de velhos crentes, as variantes da linguagem falada pelos camponeses". ${ }^{25}$

Púchkin e a língua russa vulgar, da plebe, não ao classicismo, ao eslavo eclesiástico, tão discutido em suas relações com o russo, na poesia fará o verso branco, inova a estrutura do poema, oscila para a prosa ("descer à prosa/humilde prosa"), ${ }^{26}$ na conversa com o leitor as digressões, interrupções na história do poema.

23 PÚCHKIN, 2010, p.109.

24 PÚCHKIN, 2007, p.115.

25 ANDRADE, Op.cit., p.128.

26 PÚCHKIN, 2010, p.114. 
Ao observar a quebra de expectativas no conto "O Chefe da Estação", Helena Nazario refere-se à estratégia de desautomatização do leitor por Púchkin em seu romance em versos Eugênio Onêguin: "É famosa a citação dos versos do Evguéni Oniéguin, em que Púchkin se refere com escárnio à automatização do leitor em relação ao procedimento: 'O leitor já espera a rima rosas / Aí está, tome-a, segure-a, rapidamente"'.27

A tradução de Onêguin já citada aproxima o leitor do sabor dessa ironia no texto de Púchkin: no funeral do tio "Cada um, pope ou conviva, junto/Comeu, bebeu e saiu de cena. / Com ar de que valera a pena" ${ }^{28} \mathrm{O}$ narrador dá o tom do espaço social e o tédio de Onêguin, que já tinha sido apresentado ao mundo da aristocracia russa:

Eis meu Onêguin livremente,

Cabelo em corte o mais recente,

Trajado de dandy londrino -

E enfim viu o círculo grã-fino ${ }^{29}$

Na descoberta da escolha de palavras em cada verso não se pode deixar aqui de cotejar com o original pelo menos os dois últimos versos “Как dandy ло' ндонский оде'ть - / И наконе'ц уви'дел све' т". E logo adiante: "Que mais se quer? O mundo viu (Свет реши'л) / Que tinha brilho e era gentil (Что он у'мен и о'чень мил)". ${ }^{30}$

Ora, no mundo das aparências, fica decidido assim: "Que mais se quer?" E no campo, após o funeral do tio, Onêguin se entedia. O narrador com agudeza contrapõe: "Nasci pra ter vida de paz", e "... far niente me é a lei mais certa". ${ }^{31} \mathrm{E}$ aponta para Onêguin "Por dois dias foi nova a paisagem / Com os prados em isolamento, / O bosque escuro e sua friagem, / $\mathrm{O}$ murmar do riacho lento; / Já no outro, bosque, monte e prado/ Não lhe causavam mais agrado". ${ }^{32} \mathrm{E}$ para si: "Me apraz mostrar

27 NAZARIO, Op.cit, p. 83.

28 PÚCHKIN,2019, p.69.

29 Ibidem, p.23.

30 Ibidem, p. 22-23.

31 Ibidem, p. 71.

32 Idem. 
a diferença / A toda hora entre Onêguin e eu [...] Como se não nos fosse dado/ Fazer agora um longo poema / sem ter senão a nós por tema". ${ }^{33}$

Esse narrador que se revela e nos leva para onde quer. Ele para, volta, se despede, comenta. Haroldo de Campos observa em Eugênio Onêguin a "'bravura' com que o poeta se propõe empecilhos e dele se safa", e como faz "do jogo da linguagem o principal fator de 'suspense' e interesse da narração". ${ }^{34} \mathrm{E}$ cita Chklóvski quando este se volta a Onêguin para tomá-lo como exemplo ao escrever sobre "romance paródico", em sua Teoria da Prosa - Chklóvski afirma como entrecho (siujét / сюжет) na obra de Púchkin não o romance de amor com Tatiana, mas as intervenções, digressões do narrador que interrompem 0 material fabular. E de modo a oferecer ao leitor brasileiro "uma ideia da empreitada de Púchkin, devoto - como nosso zombeteiro e cético Machado - de Laurence Sterne" ${ }^{\prime 3}$ Haroldo de Campos propõe imaginar Machado de Assis "compondo em versos seu irresolvido Dom Casmurro, cuja principal personagem", ele diria, "é não Capitu, mas o capítulo. Esse capítulo gaguejante, antecipador e antecipado, interrompido, suspenso, rememorado". 36

Na tradução, a ironia se revela na escolha de palavras como "enfim viu o círculo grã-fino"37 (o jogo com sviet / свет), quando Onêguin finalmente vê a luz é apresentado ao mundo, nos versos acima. Escolhas que marcam o justo espírito puchkiniano: "Mas há uma natureza doida", e também "da biblioteca do tinhoso". Aí vemos a linguagem límpida, frases curtas, e o jogo que atravessa cada verso. Não à toa o poeta e romancista Boris Pasternak entrega a pena ao seu personagem Jivago, que escreve:

Dentre tudo que é russo, o que eu atualmente mais gosto é do espírito infantil de Púchkin e de Tchékhov, da despreo-

33 Ibidem, p.73.

34 CAMPOS, 2004, p.63.

35 Ibidem, p. 64.

36 Idem.

37 PÚCHKIN,2019, p. 23. 
cupação acanhada de ambos diante de coisas tão turbulentas, tais como o fim último da humanidade e a sua própria salvação. ${ }^{38}$

Elena Vássina (2018) observa as diferentes traduções de Boris Schnaiderman. E distingue em seu trabalho escolhas reveladoras da escrita de Púchkin:

Por exemplo, na edição de "A dama de espadas" de 1981, determinada frase teve apenas uma palavra alterada: em vez de "Meu avô estava em franca rebelião, passamos a ler "Meu avô estava em franca revolta". Certamente, a palavra "revolta" é mais apropriada ao estilo puchkiniano e soa melhor no contexto da obra. ${ }^{39}$

Em "Púchkin - a poesia da gramática", que se encontra no dossiê dedicado ao autor no Caderno de Cultura e Literatura Russa, Haroldo de Campos ressalta:

quando Maiakóvski, no seu poema dedicado ao "Jubileu" de Púchkin, passado o primeiro momento de irritação futurista contra os "generais clássicos", convida o autor de Evguiéni Oniéguin a descer do pedestal de sua estátua e a participar com ele da revista $L E F$ e da composição de poemas-cartazes de agitação

Se você

fosse vivo, eu o faria

co-redator da $L E F$, e seria capaz

de confiar-lhe

até a poesia cartaz.

Mostrava como se faz:

- e zás! -

não duvido

com esse estilo,

você aprenderia!

não está senão rendendo um tributo de reconhecimento à extraordinária contribuição do "Africano", o orgulhoso bisneto do "Negro de Pedro, o Grande", à renovação das letras russas. ${ }^{40}$

38 PASTERNAK, 2017, p. 316.

39 VÁSSINA, Op.cit., 2018.

40 CAMPOS, Op. cit., p. 66-67. 
E Haroldo ilumina:

$\mathrm{Na}$ imprevisibilidade das chamadas 'rimas maiakovskianas', na abolição de fronteiras entre verso e prosa que os seus poemas acabam propondo, na variedade rítmica e entonacional de sua dicção trepidante [...] em tudo isso Maiakóvski parece estar reconhecendo a percussão de um miglior fabbro: Aleksandr Serguéievitch Púchkin. ${ }^{41}$

E o verso de Maiakóvski reverbera: "Nós dois / contra o lirismo,/ baioneta calada, /buscamos/ a nudez / da palavra preci$\mathrm{sa}^{\prime \prime}{ }^{42}$

\section{Em direção ao outro. A inabarcável Rússia. Uma travessia. 0 gorro do poeta persa.}

Contemporaneamente às diferentes questões de etnia e migrações, podemos ver Púchkin com as marcas de sua identidade plural como alguém capaz de fazer aparecer novas nuances e de promover aberturas. No texto "Viagem a Arzrum", Púchkin relata sua viagem ao Cáucaso e as diversas fronteiras na vastidão dessa travessia repleta de transições entre o ocidente e o oriente.

Ao final da travessia ao longo dos desfiladeiros do rio Térek, a transição instantânea do Cáucaso ameaçador para a Geórgia, o ar do sul, vales luminosos, as aldeias de terra queimada pelo calor. Até a terra ressecada dar lugar às planícies verdes e frescas da Armênia, na estrada rumo a Pérsia e Turquia. No céu, a montanha nevada de dois cumes - o Ararat, a montanha bíblica. $\mathrm{E}$ bem mais próximo, o riacho que deveriam atravessar. $O$ Arpatchai - que demarcava a fronteira com as terras turcas. E, para Púchkin, esse rio valia tanto quanto o Ararat, porque desde menino seu sonho mais querido era o de viajar, mas nunca "escapara dos limites da inabarcável Rússia". ${ }^{43}$ Finalmente, cruzaria até o outro lado. Ele escreve: "alegre, avancei

41 Idem.

42 MAIAKÓVSKI, 1983, p.97.

43 GOMIDE, 2011, p.64. 
pelo rio sagrado, e o fiel cavalo me levou para a margem turca". No entanto, é frustrado em sua travessia - "essa margem já havia sido conquistada: eu ainda me encontrava na Rússia". ${ }^{44}$ E seguirá em direção à cidade turca de Arzrum nos embates finais da campanha de 1829 contra os turcos.

Ora, sua viagem "abrange fronteiras diversas" e ele se apropriou do exterior que estava à mão, conforme lemos na apresentação que precede o relato de Púchkin na Nova Antologia do Conto Russo organizada por Bruno Gomide, onde revela: "dotado de uma capacidade ímpar de recriar gêneros literários ocidentais, o cosmopolita Aleksandr Serguêievitch Púchkin (1799-1837) nunca viajou para a Europa - e nos dois aspectos possui semelhanças com Machado de Assis". ${ }^{45} \mathrm{E}$ além da capacidade de recriar gêneros literários ocidentais e nunca ter ido à Europa, destaca outro aspecto em que o autor russo se assemelha a Machado: com este "compartilha também o proverbial 'salto' de qualidade em relação à respectiva produção literária nacional existente até então". ${ }^{46}$

O texto seria a "reelaboração - artística - de um relato de viagem que nem sempre é apresentado no rol da prosa de ficção de Púchkin"47, escreve Bruno Gomide. E na escolha do texto para compor a antologia está a sugestão de se pensar as "possíveis orientalizações das periferias russas". ${ }^{48}$

No espaço de negociações, aberturas, no caminho até o outro, um episódio se faz notar: o encontro de Púchkin com a comitiva que conduzia o poeta persa da corte, Fazil-Khan. Conta como a princípio não o levara a sério pelo gorro que esse poeta usava, e reflete sobre o engano de sua percepção quando o persa lhe responde com cortesia e sobriedade:

[...]com a ajuda do tradutor, comecei a fazer uma saudação grandiloquente à maneira oriental; mas qual não foi minha vergonha quando Fazil-Khan respondeu à minha descabida engenhosidade com a cortesia simples e inteligente de uma

44 Idem.

45 Ibidem, p.39.

46 Idem.

47 Ibidem, p.17.

48 Ibidem, p. 16 
pessoa digna! Esperava ver-me em Petersburgo; lamentava que nosso encontro fosse tão breve e assim por diante. Envergonhado, fui obrigado a abandonar o tom importante e zombeteiro e descer às frases europeias habituais. ${ }^{49}$

Decidido a nunca mais julgar alguém por sua veste, lança o detalhe de sua reflexão sobre o gorro persa (a papakkha): "De agora em diante, não julgarei um homem por sua papakha de carneiro e suas unhas pintadas". ${ }^{50}$ A possibilidade de se modificar no choque com o outro e deixar que esse embate se revele no texto traduz uma escuta. E é significativo que permaneça na reescritura do texto, quando decide revelar suas anotações, que serão publicadas sete anos depois da viagem, apenas em 1836. Na reescrita do texto a aparição do detalhe se mantém, não é riscada da narrativa. E me pergunto sobre as tensões no texto, onde algo se modifica ou se revela na relação ao outro.

Essas formas diferentes de olhar têm expressão significativa na escrita de Púchkin. E são essas formas que pretendo buscar (e mais adiante, neste estudo, em passagens de diferentes obras).

Em sua despedida de Arzrum, então "considerada a principal cidade da Turquia asiática"51 e por onde passavam as principais rotas terrestres de comércio entre a Europa e Oriente, o autor se depara com a peste. E suas reações entre repulsa e curiosidade são narradas de modo a mais uma vez desconstruir uma identidade fixa e espantar-se. Esse narrador em seu testemunho de viagem faz aparecer o que não percebera antes a respeito dos seus próprios limites, contornos, fronteiras. Em espelhamentos, colisões. Que o autor-narrador atente a isso é algo que pode ser lançado como pergunta. Essas marcas de alteridade poderiam não estar presentes. Que exista a escolha em contá-las, percebê-las no ato da escrita, mostra-nos Púchkin em mais uma fenda, abertura, nas travessias até o outro.

Terminados os embates da campanha do império russo contra os turcos, tem-se notícia da peste que assolava a re-

49 Ibidem, p. 52

50 Idem.

51 Ibidem, p. 79. 
gião. Púchkin confessa: "Imediatamente pensei nos horrores da quarentena e decidi abandonar o exército naquele mesmo dia $^{52}$. Escreve:

A ideia da presença da peste é extremamente desagradável para quem não está acostumado. Com desejo de apagar essa impressão, fui passear pela feira [...] de repente alguém bateu em meu ombro. Olhei ao redor: atrás de mim havia um mendigo horrível. Estava pálido como a morte [...] a ideia da peste passou por minha imaginação outra vez. Empurrei o mendigo com um asco indescritível e voltei para casa extremamente descontente com o meu passeio. ${ }^{53}$

Podemos nos perguntar se se aborreceu com o passeio ou com o próprio gesto. E quando relata que "no entanto, a curiosidade venceu; no dia seguinte me dirigi com um médico ao campo onde se encontravam os infectados"54 estaria, mais do que curioso, desejoso de confrontar a "imaginação" da peste com a experiência da visão da peste? De novo a "palidez" aparece em primeiro plano quando lhe trazem um doente, o que se vê é a cor que falta: "estava extraordinariamente pálido e cambaleava como um bêbado". ${ }^{55} \mathrm{E}$ sua atenção se dirige aos homens que levavam o outro doente até a tenda: "voltei a atenção a dois turcos que o carregaram pelos braços". É quando Púchkin, protegido na direção do vento, admite que ficou envergonhado por seu "acanhamento europeu" diante da doença, ante a indiferença dos dois turcos.

Volto a um trecho do relato que revela essa qualidade de distanciamento das coisas. Ainda no acampamento, depois da tomada de Arzrum, quando os representantes turcos já entregavam a chave da cidade, em meio à rendição e à lida com os grupos revoltosos dá-se a conversa entre os generais e um dos paxás aprisionados. Este paxá, ao se inteirar de que ali estava um poeta, surpreende Púchkin com uma saudação oriental, da qual o autor toma nota:

52 Ibidem, p. 83.

53 Ibidem, p. 84

54 Idem.

55 Idem. 
Abençoada seja a hora em que encontramos um poeta. $O$ poeta é irmão do dervixe. Ele não possui nem pátria, nem bens terrenos; e enquanto nós, pobres, nos preocupamos com glória, poder e tesouros, ele está lado a lado com os reis da Terra e é por todos reverenciado. ${ }^{56}$

Púchkin assinala no texto: "a saudação oriental agradou a todos". Para, no entanto, registrar cena significativa:

Ao sair da tenda, vi um jovem seminu, com um gorro de carneiro, uma vara na mão e com um odre (outre) nos ombros. Ele gritava a plenos pulmões. Me disseram que era meu irmão, um dervixe, que viera cumprimentar os vencedores. Enxotaram-no a duras penas. ${ }^{57}$

E de novo um gorro aparece, o gorro de carneiro, não no poeta, mas em seu irmão dervixe. Irmão expulso, e seu grito silenciado a duras penas. Nessa relação de espelhamentos, reflexos, revela-se o outro lado, o poeta puxa a linha desse gorro e o desfia, busca o seu avesso. O lado do avesso onde aparecem os rastros. Cena expressiva lançada no ar, ao final do capítulo. Como se no mundo o lugar do poeta não fosse algo tão reverenciado assim. Também ele, um dia, teria que pagar por insistir na sua liberdade escrita a plenos pulmões.

Enfim, na travessia terá encontrado o poeta persa, o paxá turco e o dervixe, e também cossacos, cazaques, nogais, tártaros, ossetas, calmucos, iazidi... e a estes últimos perguntará se de fato reverenciam Satanás.

Às minhas perguntas, respondeu que os boatos de que os iazidi adoram Satã são pura invenção; eles acreditam em um único Deus; que por sua lei, é verdade, amaldiçoar o diabo é considerado indecoro e vil, pois agora ele é infeliz, mas com o tempo pode ser perdoado. ${ }^{58}$

E Púchkin fica tranquilo com sua explicação. A literatura aproxima olhares que viram o mundo pelo avesso.

56 Ibidem, p. 78.

57 Idem.

58 Ibidem, p. 70 


\section{Ao longo da História, omissões, branqueamentos}

Púchkin, na literatura russa, neste mundo de deslocamentos, migrações, é capaz de acolher o outro. É quando o leitor à margem percebe que ele diz a sua voz, a sua letra, pois o que disse na letra era de um lugar obtuso, não do centro, e então se torna outro como ele também. Instaura a dúvida e no disparate de ações de suas personagens é fonte para um autor como Dostoiévski trabalhar a complexidade da alma humana. E Machado, na literatura brasileira, suas personagens no olhar para as convenções, o distanciamento que aponta a máscara social, o contar em silêncios, a forma do conto que não conta e apenas sugere. Intriga o leitor e o chama à cena. Machado, leitor dos russos. Machado negro. Púchkin negro. No alfinete, na trama, na ponta do lápis, a crítica, a dúvida, a pergunta. E é preciso perguntar, sempre.

Ora, em 2018, mais uma foto de Machado de Assis foi descoberta. Publicada originalmente em 25 de janeiro de 1908 na revista semanal argentina Caras y Caretas, a foto do escritor foi redescoberta pelo pesquisador independente Felipe Pereira Rissato. De acordo com Rissato, o retrato era desconhecido - e trata-se, possivelmente, do último do autor.

No caso brasileiro, em Machado o branqueamento se dá não apenas nas gravuras, mas também nos silenciamentos, nessa ausência de referências à sua etnia. Aspectos importantes eram convenientemente deixados de lado. Com a literatura nas escolas estudadas de forma a memorizar dados e datas, muitas vezes Machado em fotos onde o branqueamento é notório.

Em artigo de João Cezar de Castro Rocha para a revista Veja logo após a descoberta dessa última foto de Machado, lemos:

Um mês após a morte do escritor, ocorrida em 29 setembro de 1908, o crítico José Veríssimo, grande amigo de Machado, escreveu um elogio no Jornal do Commercio, incluindo a sentença: "Mulato, foi de fato um grego da melhor época, pelo seu profundo senso de beleza, pela harmonia de sua vida". Outro amigo dileto, o Embaixador Joaquim Nabuco, 
reagiu com rispidez numa carta nada diplomática: "Eu não teria chamado o Machado mulato e penso que nada lhe doeria mais do que essa síntese (...). O Machado para mim era um branco, e (...) quando houvesse sangue estranho, isso em nada afetava a sua perfeita caracterização caucásica. Eu pelo menos só vi nele o grego". ${ }^{59}$

\section{E João Cezar comenta, ao final:}

Estampada na revista argentina Caras y Caretas, no ano de sua morte, o Machado de corpo inteiro é um homem evidentemente preto. Perfeitamente trajado, a barba e o bigode irretocáveis, apresentado como "presidente de la Academia de la Lengua Brasileña", ainda assim, ou por isso mesmo, esse instantâneo afro-brasileiro rompe com o modelo ático legado à posteridade.60

Esse modelo "atenuante" das raízes negras de Machado por seus pares esbarra em processo semelhante em Púchkin até as novas descobertas. Segundo o artigo de Serge Schmemann para o The New York Times, ${ }^{61}$ escrito em La Fére, França exatamente onde Abrão Anibal se graduou, na academia de artilharia real - a tese do historiador Dieudonné Gnammankou, ele mesmo de Benin, especialista da diáspora africana na Europa e eslavófilo, causou um impacto na Rússia. Raízes na África negra, diria Gnammankou, pareceriam menos aceitáveis que raízes no antigo império cristão da Etiópia. O que Boris Schnaiderman ressalta em sua pesquisa sobre a recepção de Púchkin pelos historiadores em seu "Prefácio" a Dama de Espadas comentado por Elena Vássina: os traços que o poeta russo deixou do orgulho de sua etnia podem ter sido omitidos. De novo, ecoa a questão - como "conceber que um negro desempenhasse papel tão importante e fosse um antecessor direto do poeta nacional dos russos". ${ }^{62}$

É interessante observar que inicialmente se pensava o bisavô Púchkin como abissínio. O Império Etíope, também conhecido como Abissínia, ocupou os atuais territórios da Etiópia e

59 CEZAR, 2018.

60 Idem.

61 SCHMEMANN, 2010.

62 SCHNAIDERMAN, 1999, p.10. 
da Eritreia. Mas o único fato conhecido foi que o próprio Abrão Anibal contou numa carta à filha de Pedro, o Grande, a imperadora Elizabeth, que ele era da cidade de Lagon. E o historiador Gnammankou, em 1995, chegar à conclusão de que Lagon era Logone, a capital do antigo Kotoko, reino de Logone-Birni ao sul do lago Chad, atualmente ao norte de Camarões.

Lembro-me de quando, ainda na graduação em Letras na UERJ, bolsista de iniciação científica orientada pela Professora e Pesquisadora Cida Salgueiro, visitei o Centro Cultural José Bonifácio, na Gamboa, no Rio de Janeiro, para encontrar-me com Conceição Evaristo. Durante nossa conversa, ela me mostrou uma imagem que revelava o Machado de Assis negro. Nos últimos anos, não cessam os esforços de pesquisadores como Eduardo de Assis Duarte na recepção de Machado, e marco importante foi o lançamento em 2011 de sua Antologia crítica em quatro volumes Literatura e afrodescendência no Brasil. Como organizador, revê o conceito de cânone não apenas pela própria elaboração da antologia, incluindo autores e autoras que construíram espaços independentes para sua escrita, mas também pela inserção de autores canônicos como Machado de Assis, revendo a forma de sua recepção. As margens aproximando-se do centro e operando ali uma desconstrução, revelando os acidentes, riscos então apagados, desses abrandamentos que escondem e não negociam fronteiras, erigem muros para não acolher a diversidade das margens em seu tráfego cultural.

Importante, nessa perspectiva, ainda outra questão. Nos últimos anos Machado foi relido de forma a revelar que sim, voltou sua atenção e crítica ao passado escravagista. Para tanto, com esse novo olhar, a leitura do conto "Pai contra mãe" que fala da escravidão. Publicado após a abolição da escravatura, aponta, no entanto, para um período anterior, revelando um sistema cruel em cada espaço que ocupa, nos diferentes graus de poder. No conto, o caçador de escravos já quase não tem trabalho, escasseavam os negros fugidos. Em vez de capitão do mato, ele é um trabalhador pobre, com família, que pensa 
no filho que terá de abandonar, caso não ganhe algum dinheiro. Este é o pai a que se refere o título do conto. A mãe, descobrimos, é a escrava fugitiva, que está grávida. Ela já tinha escapado havia algum tempo, e parecia estar tranquila à luz do dia, quando é avistada pelo caçador. Faltava pouco para esta mãe dar à luz. No confronto entre os dois, pai e mãe, podemos pensar que está em xeque a quem pertence o direito à felicidade. $E$ até que ponto não fica a pergunta - questão atual em nosso país - sobre quem tem o direito à vida. Na hipocrisia dos lugares sociais, na ironia do encontro, a condição trágica do negro (que na época histórica, ainda que tenha recebido a alforria, é privado de direitos e espaços). Na violência da captura, a mãe perde a criança, e Machado termina o conto com a frase - "Nem todas as crianças vingam" - seca e cruel, aponta o cinismo de uma sociedade partida. Onde, se você está do lado errado, o mundo não estará a seu favor.

Machado nasceu em 1839, na cidade do Rio de Janeiro, no Morro do Livramento, dois anos após o falecimento de Púchkin. Passou a infância entre a casa pobre dos pais e a casa rica da madrinha de batismo, Dona Maria José de Mendonça, viúva de um senador. Com a morte da mãe e, depois, do pai, ficou com sua madrasta negra, Maria Inês. Para sobreviver, ela fazia quitutes, que ele vendia pelas ruas. Ainda adolescente, estudou francês ao frequentar a casa de Mme. Gallot. Pensando em Machado afrodescendente, revemos constantemente o corpo da literatura negra ou afro-brasileira que assim se coloca de modo a existir, sem esperar por uma "autorização". As vozes nessas linhagens que se reinauguram e se reinventam também surgem a cada novo esforço em repensar o cânone, 0 já estabelecido.

Machado de Assis é relido em sua crítica a um passado escravagista por pesquisadores como Eduardo de Assis Duarte. Maria Nazareth Soares Fonseca assinala: Duarte "identifica a posição irônica de Machado de Assis contra os senhores de escravos e a exposição crítica dos mecanismos utilizados pelas elites para prolongar os benefícios advindos da escravidão" 63

63 DUARTE, 2011, p. 256. 
os quais "tornam-se evidentes em sua literatura, que também se empenhou em apontar os desmandos dos senhores de escravos e a situação de penúria vivida pelos africanos e seus descendentes no Brasil". ${ }^{64}$

Referindo-se ao conto "Pai contra mãe", Duarte irá refletir como Machado reconstrói a memória da escravidão. E isso com um narrador que se identifica "não com a classe social que ele critica, mas sim com os irmãos vítimas do sistema escravocrata. E mostra como o conto desafia a voz que tenta atenuar o processo violento da escravidão no Brasil". ${ }^{65}$

Ora, se virmos o começo do conto, fala-se das máscaras que infligiam aos escravos para lhes tapar a boca e curar-lhes o alcoolismo. A máscara de folha de Flandres com três buracos, dois para ver e um para respirar. Cada frase traz a ironia no que expõe a crueldade como se fora algo bem comum. Abandonado o vício, "perdiam a tentação de furtar, porque geralmente era dos vinténs do senhor que eles tiravam com que matar a sede, e aí ficavam dois pecados extintos, e a sobriedade e a honestidade certas". ${ }^{66} \mathrm{~A}$ cada nova frase mais um escavar afiado, seco e pleno de ironia. "Era grotesca a tal máscara, mas a ordem social e humana nem sempre se alcança sem o grotesco, e alguma vez o cruel" ${ }^{67}$ Muito naturalmente aprendemos que as máscaras podiam ser compradas à vontade nas lojas. E o narrador anuncia num corte: "Mas não cuidemos de máscaras".

E havia o ferro para o pescoço, usado para conter os "escravos fujões", ao que o narrador de Machado observa: "há meio século, os escravos fugiam com frequência. Eram muitos, e nem todos gostavam da escravidão". O narrador nos faz estranhar o fato de que houvesse uma ou outra fuga eventual, e reflete: "Sucedia ocasionalmente apanharem pancada, e nem todos gostavam de apanhar pancada" ${ }^{68}$ Os comentários desse

64 Idem.

65 FUENTES, 2012, p. 92.

66 RUFFATO, 2010, p. 59.

67 Idem.

68 Ibidem, p.60. 
narrador parecem criar outro plano de leitura, o tom do absurdo, que evidencia parte de nossa história, da formação do país.

Aqui a necessidade de se repensar o cânone em suas marcas de alteridade. O Brasil à luz do escurecimento, "onde a negritude não se separa das vozes que compõe ou narram a nação, mas vem como autocelebração, como memória e como futuro de um componente africano que se insere no contexto contemporâneo brasileiro". 69

Como escreve Maria Aparecida Andrade Salgueiro, no artigo "Literature, Written Art and Historical Commitment: From Cadernos to Conceição Evaristo", a noção de cânone vem ela mesma sendo discutida:

"Num momento histórico em que o termo 'globalização' é ainda debatido, lutas e rebeliões nacionalistas se impõe, e a ideia de 'nação' de acordo com parâmetros tradicionais é altamente questionada, era de se esperar que a noção de cânone também fosse desafiada. ${ }^{70}$

Assim, repensar o cânone em seu diálogo com o contemporâneo. Em cada palavra para escurecer a folha, um novo Púchkin. Machado em mais uma casa. A estátua de Púchkin em Asmara, Eritreia. E na Etiópia. E enfim Logone-Birni, Camarões. Púchkin me faz procurar no mapa. O lago Chad. E a memória fala de outro encontro, este em novembro do ano passado, quando na primeira noite nas ruas de Moscou, no caminho para o teatro, de repente Púchkin, sua estátua na Tverskaia aparece diante de mim. Ainda não planejara os trajetos, chegara na véspera debaixo de chuva e inesperadamente ali estava o poeta, sobre seus ombros a lua e todo o céu de Moscou. No mesmo chão por onde andou Dostoiévski em seu discurso da Praça Púchkin. Esse poeta que os russos sabem de cor. E, de fato, quando voltei durante o dia à mesma praça, encontrei o menino com seu avô que lhe levava para conhecer o poeta. Era novembro, fazia frio, havia poucas pessoas, conversamos e 0

69 FUENTES, Op. cit., p. 92.

70 SALGUEIRO, 2011, p.9, tradução minha. "At a historical moment when 'globalization' is still much talked about, when nationalist rebellions and struggles succeed, when the very notion of 'nation' according to traditional parameters is strongly questioned, it is not surprising that the notion of 'canon' is also being challenged." 
pequeno Kiril me falou um poema de Púchkin. Esquecia-se de uma parte, depois lembrava. Na despedida, eu contei que era do Brasil, passou um tempinho e eles voltaram. $O$ avô disse: então ele vai declamar para você outro poema. Kiril não falava sem pensar, enxergava as palavras. E foi aí que perguntei seu nome. Devia ter uns sete anos. E fico pensando quantas coisas não acontecem através dos séculos. Naquela praça. E passo pelo Catete onde há um pedaço de mármore e onde se lê sobre Machado de Assis. Paro em rito de leitura, nesse lugar sem pouso, esquina. E penso nas ruas e como a literatura escreve a cidade, e na importância de narrativas culturais que possam asilar, receber, nesse universo de recusas, o outro. Para habitar o poema, a linha, o livro, a praça.

\section{Referências bibliográficas}

ANDRADE, Homero Freitas de. "Dossiê Púchkin". In: Caderno de literatura e cultura russa. Curso de Russo/ Departamento de Letras Orientais/ FFLCH/ USP. São Paulo: Ateliê Editorial, 2004, pp. 27-235.

ASSIS, M. Obra completa. Org. Afrânio Coutinho. Rio de Janeiro: Editora Nova Aguilar, 1985.

ASSIS, M. Contos / Uma Antologia. Seleção, Introdução e Notas de John Gledson. São Paulo: Companhia das Letras, 2016.

CAMPOS, Haroldo de. "Púchkin, a poesia da gramática". In: Caderno de Literatura e Cultura Russa. Curso de Russo/ Departamento de Letras Orientais/ FFLCH/ USP, São Paulo, março 2004, n.1, pp. 61-68.

DUARTE, Eduardo de Assis (org.) Literatura e afrodescendência no Brasil: antologia crítica. Belo Horizonte: EdUFMG, 2011. $4 \mathrm{v}$.

FUENTES, Susana. "Outros viram também. Uma experiência do olhar em 'Re(considerando) a negritude em (con)textos contemporâneos afro-brasileiros' de Antonio D. Tillis". Revista The Publication of the Afro-Latin/American Research Association (PALARA), n. 17, Hanover, New Hampshire, outono, 2013, pp. 87-96. GOMIDE, Bruno Barretto (org.) Nova Antologia 
do Conto Russo (1792-1998). São Paulo: Editora 34, 2011. MAIAKÓVSKI, Vladímir. "Jubileu" Tradução de Haroldo de Campos. In: _-_. Maiakóvski, poemas. São Paulo: Perspectiva, 1983. pp. 95-103.

NAZARIO, Helena. "Humor e Irreverência na Prosa de Púchkin". Em: Caderno de Literatura e Cultura Russa. Curso de Russo/ Departamento de Letras Orientais/ FFLCH/ USP. São Paulo: Ateliê Editorial, 2004. pp. 77-84.

PASTERNAK, Boris. Doutor Jivago. Tradução do russo Sonia Branco, tradução dos poemas Aurora Fornoni Bernardini. São Paulo: Companhia das Letras, 2017.

PHILLIPS, Mike. "Black Europeans. Alexander Pushkin (17991837)". The British Library, Galeria Online. s.d. Disponível em: https://www.bl.uk/onlinegallery/features/blackeuro/pdf/ pushkin.pdf Acesso em: 21/04/2020.

PÚCHKIN, Aleksandr. Boris Godunov. Tradução, notas e posfácio de Irineu Franco Perpetuo. São Paulo: Editora Globo, 2007.

PÚCHKIN, Aleksandr. A Dama de Espadas. Tradução de Boris Schnaiderman. São Paulo: Max Limonad, 1981.

PÚCHKIN, Aleksandr. Eugênio Onêguin - Um Romance em Versos. Tradução de Alípio Correia da Franca Neto e Elena Vássina, v.1. Edição bilíngue. São Paulo: Ateliê Editorial, 2019. PÚCHKIN, Aleksandr. Noites egípcias e outros contos. Organização e tradução de Cecília Rosas. São Paulo: Hedra, 2010. PÚCHKIN, Aleksandr. "Viagem a Arzrum: durante a campanha de 1829". Tradução de Cecília Rosas. In: GOMIDE, Bruno Barretto (org. e apresentação) Nova Antologia do Conto Russo (1792-1998). São Paulo, Editora 34, 2011. p 39-85.

ROCHA, João Cezar de Castro. "O que mostra uma imagem recém-descoberta de Machado de Assis - Fotografia resgata dado atenuado deliberadamente em sua iconografia: a pele negra", Revista Veja, 08 jul. 2018. Disponível em: https:// veja.abril.com.br/entretenimento/o-que-mostra-uma-imagem-recem-descoberta-de-machado-de-assis/ Acesso em: $20 / 04 / 2020$ 
RUFFATO, Luiz (Organização, prefácio e seleção). Questão de Pele. Rio de Janeiro: Língua Geral, 2010.

SALGUEIRO, Maria Aparecida Andrade. "Literature, Written Art and Historical Commitment: From Cadernos to Conceição Evaristo". IN: TILLIS, A. D. (Org.) (Re)Considering Blackness in Contemporary Afro-Brazilian (Con)Texts. v.1 Nova Iorque: Peter Lang, 2011., pp 7-26.

SCHMEMANN, Serge. "Of African Princes and Russian Poets" The New York Times, La Fère, France, 12 nov. 2010. Disponível em: https://www.nytimes.com/2010/11/13/opinion/13iht-edschmemann.html?auth=link-dismiss-googleltap Acesso em: $20 / 04 / 2020$

SCHNAIDERMAN, Boris. "Nota do Tradutor". In: PÚCHKIN, Aleksandr. A Dama de Espadas. São Paulo: Max Limonad, 1981, pp. 1-2.

SCHNAIDERMAN, Boris. "Prefácio". In: PÚCHKIN, Aleksandr. A dama de espadas. Prosa e poemas. São Paulo: Editora 34, 2006. pp. 7-15.

VÁSSINA, Elena. "Boris Schnaiderman e Aleksander Púchkin: dois iniciadores". Literatura e Sociedade, v. 23, n. 26, 30 jul. 2018, pp. 56-67.

Recebido: em 26/04/2020 Aceito: em 30/05/2020 Publicado: em junho de 2020 